\title{
Salinity Influences Photosynthetic Characteristics, Water Relations, and Foliar Mineral Composition of Annona squamosa L.
}

\author{
Thomas E. Marler \\ College of Agriculture and Life Sciences, University of Guam, UOG Station, Mangilao, Guam 96923
}

\author{
Yasmina Zozor \\ Fairchild Tropical Garden, 11935 Old Cutler Road, Miami, FL 33156
}

Additional index words. apparent quantum yield, chlorophyll fluorescence, dark respiration, net $\mathrm{CO}_{2}$ assimilation, osmotic potential, photosynthesis, stomatal conductance, sugar apple, transpiration, water use efficiency

\begin{abstract}
Leaf gas exchange, chlorophyll fluorescence, water relations, and mineral nutrient relations responses of Annona squamosa seedlings to mild salinity were studied in sand culture in five experiments during 1990, 1991, and 1993. Trees were irrigated with a complete nutrient solution (control) or with this solution amended to 3 or $6 \mathrm{dS} \cdot \mathrm{m}^{-1}$ with sea salt. Inhibition of net $\mathrm{CO}_{2}$ assimilation, stomatal conductance of $\mathrm{CO}_{2}$, and transpiration was apparent within 2 weeks of initiating salinity treatments, and gas exchange continued to decline until day 30 to 35 . The diurnal pattern of leaf gas exchange was not altered by increased salinity. Salinity reduced $\mathrm{CO}_{2}$, light energy, and water-use efficiencies. Salinity sometimes reduced the ratio of variable to maximum fluorescence below that of the control, and this response was highly dependent on the ambient light conditions that preceded the measurements. Dark respiration was unaffected by salinity stress. Root zone salinity of $\mathbf{3} \mathrm{dS} \cdot \mathrm{m}^{-1}$ administered for 52 days did not influence foliar sodium concentration or the ratio of sodium to potassium, but increased chloride concentration and decreased nitrogen concentration. The sodium response indicated that some form of exclusion or compartmentation occurred. Salinity reduced osmotic potential of root tissue but did not influence foliar osmotic or predawn xylem potential. These results indicate that $A$. squamosa is sensitive to salinity stress, and that the responses to salinity are consistent with other salt-sensitive woody perennial species.
\end{abstract}

The tropical sugar apple (Annona squamosa) is one of the most widely planted Annona species grown throughout the lowland tropics (Morton, 1987). With increasing human activities along coastal areas in the lowland tropics, a more balanced understanding of the ecology of these habitats is needed. Plants being grown in tropical coastal areas may be exposed to salinity by wind-borne salt or from sea-water intrusion (Maas, 1994). Moreover, water for irrigation of crops is generated by pumping from a subterranean fresh water lens on many tropical islands. Poorly designed wells or water use that exceeds the sustainable yield of the water lens commonly leads to influx of underlying salt water (Singh et al., 1994). An understanding of plant responses to salinity is needed to develop an operative approach to manage tropical coastal areas.

Salinity effects on plant growth and yield depend in part on factors that affect carbon acquisition (Yeo, 1983). Photosynthesis is usually lower in plants exposed to salinity and may decline with time of exposure (Munns and Termaat, 1986). The degree of inhibition by saline conditions varies greatly among species, as do the mechanisms involved in inhibition (Gale, 1975).

Keleg et al. (1980) reported on growth responses of $A$. senegalensis Pers. to salinity; however, responses of other Annona species to this environmental stress have not been established (Maas, 1994). Moreover, we know of no reports that have described the photosynthetic characteristics of A. squamosa. These studies were conducted to determine leaf gas exchange, chlorophyll fluorescence, water relations, and nutrient uptake responses of A. squamosa to mild salinity.

Received for publication 17 May 1995. Accepted for publication 12 Oct. 1995. The cost of publishing this paper was defrayed in part by the payment of page charges. Under postal regulations, this paper therefore must be hereby marked advertisement solely to indicate this fact.

\section{Materials and Methods}

Experiment 1. Eighteen-month-old A. squamosa plants were obtained from a commercial nursery in Jan. 1990 and transferred to a whitewashed glasshouse in Miami, Fla. Maximum photosynthetic photon flux (PPF) was about $1200 \mu \mathrm{mol} \cdot \mathrm{m}^{-2} \cdot \mathrm{s}^{-1}$ in the glasshouse, and the plants were bare-rooted and repotted in silica sand in 2.6-liter containers. Nutrient solution was applied by hand at $200 \mathrm{ml}$ per container each day. The nutrient solution was made with $0.68 \mathrm{~g} \cdot$ liter $^{-1}$ Hydro-Sol (W.R. Grace \& Co, Fogelsville, Pa.) and $0.45 \mathrm{~g} \cdot$ liter $^{-1}$ calcium nitrate. This solution was diluted to 1 $\mathrm{dS} \cdot \mathrm{m}^{-1}$ and had a $\mathrm{pH}$ of 6.7 to 7.0 . The complete nutrient solution concentration after dilution was based on $6.9 \mathrm{~mm}$ nitrogen, which was about $90 \%$ of half-strength Hoagland solution (Hoagland and Arnon, 1950).

Salinity treatments were selected as 1 (control), 3 , or $6 \mathrm{dS} \cdot \mathrm{m}^{-1}$, with respective osmotic potentials of $-0.04,-0.12$, or $-0.25 \mathrm{MPa}$. Salt levels of 3 and $6 \mathrm{dS} \cdot \mathrm{m}^{-1}$ were made by adding sea salt to the control solution. Treatments were imposed on 1 Apr. when the plants were $45 \pm 2 \mathrm{~cm}$ (mean $\pm \mathrm{sE}$ ) in height. Electrical conductivity (EC) was increased $1 \mathrm{dS} \cdot \mathrm{m}^{-1}$ per day until reaching $3 \mathrm{dS} \cdot \mathrm{m}^{-1}$ on 3 Apr. or $6 \mathrm{dS} \cdot \mathrm{m}^{-1}$ on 6 Apr. Solutions continued to be applied by hand at $200 \mathrm{ml}$ per container per day. This application rate was adequate enough in this and all subsequent experiments to ensure $>25 \%$ drainage of applied solution.

The treatments were arranged in a randomized complete-block design $(n=6)$ to determine the developmental responses of leaf gas exchange to salinity. Mean day/night temperatures were $31 \pm 1 / 20$ $\pm 2 \mathrm{C}$, and relative humidity ranged from $51 \% \pm 2 \%$ to $87 \% \pm 2 \%$ for the duration of the study, determined by hygrothermograph (WEATHERtronics model 5020, Qualimetrics, Sacramento, Calif.).

Leaf gas exchange was determined with an open photosynthesis system using a Parkinson broadleaf chamber (LCA-2, Analyti- 
cal Development Co., Hoddesdon, Herts, U.K.) beginning on 30 Mar. (day -2), and every 4 to 6 days until 9 May (day 38). One leaf per plant was selected for each measurement period at about 2-h intervals throughout each photoperiod of measurements. Only the youngest, fully expanded leaves were chosen on all plants for this and all other studies. Outside air was supplied to the leaf chamber at the rate of $375 \mathrm{ml} \cdot \mathrm{min}^{-1}$.

Means and standard errors were determined for each salinity treatment to determine the daily time course of net $\mathrm{CO}_{2}$ assimilation $\left(\mathrm{A}_{\mathrm{CO}_{2}}\right)$, stomatal conductance of $\mathrm{CO}_{2}\left(\mathrm{~g}_{\mathrm{c}}\right)$, and transpiration (E). Comparisons of gas-exchange characteristics within a specific time period were accomplished by determining linear and quadratic models with salinity level as the independent variable. Diurnal gas-exchange data were analyzed as a salinity $\times$ time of day factorial.

Experiment 2. Plant preparation and the experimental conditions for this study were as described in Expt. 1. However, no leaf gas-exchange measurements had been made on these plants before 14 May, since gas exchange of this species is sensitive to repeated loading of leaves in measurement cuvettes (Marler and Mickelbart, 1992).

Plants receiving 1 or $3 \mathrm{dS} \cdot \mathrm{m}^{-1}(\mathrm{n}=4)$ were used to determine the response of $\mathrm{A}_{\mathrm{CO}_{2}}$ to external $\mathrm{CO}_{2}$ as described by Marler et al. (1993) using a Li-Cor 6200 portable photosynthesis system with a Li-Cor 6250 gas analyzer and a 1-liter chamber (Li-Cor, Lincoln, Neb.). The plants were transferred from the glasshouse to a laboratory for measurements on 14-15 May (days 43-44). Leaf area of $13 \mathrm{~cm}^{2}$ was exposed in the chamber, and laboratory conditions were $2.6 \mathrm{kPa}$ vapor pressure deficit (VPD), 30C, and $\mathrm{PPF}$ of about $1160 \mu \mathrm{mol} \cdot \mathrm{m}^{-2} \cdot \mathrm{s}^{-1}$. The range of external $\mathrm{CO}_{2}$ was 100 to $650 \mu \mathrm{l} \cdot$ liter $^{-1}$.

Experiment 3. Nineteen-month-old A. squamosa trees were prepared, placed in the glasshouse, and irrigated with complete nutrient solution as described for Expt. 1. Plants were grown under these conditions from 7 Dec. 1990 until 9 Feb. 1991, when they averaged $50 \pm 2 \mathrm{~cm}$ in height.

Treatments consisted of 1 (control) and $3 \mathrm{dS} \cdot \mathrm{m}^{-1}$. Salinity was increased $1 \mathrm{dS} \cdot \mathrm{m}^{-1}$ per day beginning $9 \mathrm{Feb}$. About $300 \mathrm{ml}$ of solution was applied to each container once daily from elevated tanks to dribble ring emitters via polyethylene tubing and microtubing. The plants were arranged in a randomized complete-block design $(n=6)$ to repeat measurement of the developmental response of $\mathrm{A}_{\mathrm{CO}_{2}}$ to salinity and determine chlorophyll fluorescence responses to salinity. Growing conditions during this study were $19 \pm 2$ and $32 \pm 1 \mathrm{C}$ (temperature extremes) and $50 \% \pm 2 \%$ and $92 \% \pm 2 \%$ (relative humidity extremes).

Leaf gas-exchange measurements were made during midday (based on diurnal patterns from 1990) using the Li-Cor system described in Expt. 2. One leaf per plant was chosen at random and placed in the chamber with $11 \mathrm{~cm}^{2}$ of leaf surface exposed. Measurements begun on 7 Feb. 1991 (day -2) and continued through 22 Mar. (day 39) on 3- to 6-day intervals.

Induction kinetics of chlorophyll fluorescence were determined from the adaxial surface of leaves using a Brancker SF-30 fluorometer (Richard Brancker Research, Ottawa, Canada). The plants were transferred from the glasshouse to a darkroom on 30 Mar. 1991 at 1300 HR (day 47). Instantaneous ( $\left.\mathrm{F}_{\mathrm{o}}\right)$ and maximal $\left(\mathrm{F}_{\mathrm{m}}\right)$ fluorescence yields were recorded on two laminae per plant after dark acclimation for $30 \mathrm{~min}$. Measurements were made halfway between midrib and margin at the midpoint of each leaf. Variable fluorescence $\left(\mathrm{F}_{\mathrm{v}}\right)$ was calculated from the difference, followed by calculation of the fluorescence ratio $\left(\mathrm{F}_{\mathrm{v}}: \mathrm{F}_{\mathrm{m}}\right)$. Fluorescence ratio data were subjected to analysis of variance.
Experiment 4. Six plants per treatment were arranged in a randomized complete block on the bench with the plants used in Expt. 3 to determine salinity effects on photosynthetic response to irradiance. Three plants per treatment were selected at random to determine the response of $\mathrm{A}_{\mathrm{CO}_{2}}$ to light on 27-28 Mar. (days 4445). The plants were transferred to a laboratory for measurement and analysis as described by Marler et al. (1994), using the Li-Cor system described in Expt. 2. Laboratory conditions of $2.2 \mathrm{kPa}$ VPD, $34 \mathrm{C}$, and $396 \mu \mathrm{l} \cdot$ liter $^{-1} \mathrm{CO}_{2}$ were maintained within the chamber, with $11 \mathrm{~cm}^{2}$ leaf area exposed. Dark respiration was determined with the Li-Cor system on the morning of 29 Mar. 1991 (day 46). Methods and analysis were as described by Marler et al. (1994).

Experiment 5. Fourteen-month-old A. squamosa plants were bare-rooted and repotted in silica sand, then placed in a plastic greenhouse (maximum PPF about $1300 \mu \mathrm{mol} \cdot \mathrm{m}^{-2} \cdot \mathrm{s}^{-1}$ ) in Guam. The plants were irrigated with complete nutrient solution, as previously described, and grown under these conditions from 21 May until 21 July 1993, when they averaged $46 \pm 2 \mathrm{~cm}$ in height. Salinity treatments of 1 or $3 \mathrm{dS} \cdot \mathrm{m}^{-1}$ began on 21 July on plants arranged in a completely randomized design $(n=6)$. Growing conditions during this study were $24 \pm 2$ and $33 \pm 1 \mathrm{C}$ (temperature extremes) and $76 \% \pm 2 \%$ and $91 \% \pm 2 \%$ (relative humidity extremes).

Photosynthetic response to PPF was determined on 27 Aug. (day 37) as described in Expt. 4. Gas exchange was determined from $2.5 \mathrm{~cm}^{2}$ of one leaf per plant using an open system (CIRAS1, PP Systems, Stotfield, Hitchin, Herts, U.K.). Irradiance levels ranged from darkness to $1380 \mu \mathrm{mol} \cdot \mathrm{m}^{-2} \cdot \mathrm{s}^{-1}$. Conditions during measurements were $1.0 \mathrm{kPa} \mathrm{VPD}, 32 \mathrm{C}$, and 345 to $350 \mu \mathrm{l} \mathrm{CO}_{2} /$ liter.

Chlorophyll fluorescence was determined on several days between 3 and 11 Sept. Following 3 to $4 \mathrm{~h}$ of exposure to sunlight (1200 to $1300 \mathrm{HR}$ ), fluorescence was measured with PPF of excitation light at $900 \mu \mathrm{mol} \cdot \mathrm{m}^{-2} \cdot \mathrm{s}^{-1}(\mathrm{CF}-1000$, P.K. Morgan, Andover, Mass.). Dark adaptation of $30 \mathrm{~min}$ was administered on three leaves per plant with the system cuvettes before measurements.

Predawn xylem potential $\left(\psi_{\mathrm{x}}\right)$ was measured (PMS 650 pressure chamber, PMS Industries, Corvallis, Ore.) on two leaves per plant on 11 Sept. (day 52). Leaf tissue and root tissue were harvested from each of the plants on the same day to terminate the study. Root sections $2 \mathrm{~cm}$ in length were prepared from roots within the range of 1 to $2 \mathrm{~mm}$ in diameter. This tissue was washed in deionized water and frozen. Petioles of two leaves per plant were placed in deionized water for $12 \mathrm{~h}$ to ensure the leaves were fully rehydrated before washing and freezing. The frozen leaf and root tissue was thawed and osmotic potential $\left(\psi_{\pi}\right)$ was determined on expressed solution by vapor pressure osmometry (model 5500, Wescor, Logan, Utah) as described by Markhart and Lin (1985). The remainder of the leaves was washed, consolidated into three samples of two trees each, and dried at 70C. Calcium, chloride, nitrogen, potassium, and sodium content were determined on a dry weight basis (Wolf, 1982).

The data in Expt. 5 resulting from methods repeated from earlier experiments were analyzed as previously described. The remaining data from Expt. 5 were subjected to analysis of variance.

\section{Results}

Developmental response of gas exchange. Data were taken from late morning on each of the measurement days in Expt. 1 and analyzed to determine the developmental response of leaf gas 
exchange to salinity. A decline in $\mathrm{A}_{\mathrm{CO}_{2}}$ (relative to control) occurred beginning on day 14 for plants in 3 and $6 \mathrm{dS} \cdot \mathrm{m}^{-1}$ treatments (Fig. 1). The decline continued until about day 35 , when $\mathrm{A}_{\mathrm{CO}_{2}}$ was $48 \%$ or $35 \%$ of control values for 3 or $6 \mathrm{dS} \cdot \mathrm{m}^{-1}$, respectively, and measurements were terminated. Similar patterns occurred for $\mathrm{g}_{c}$; however, the decline following day 14 was more rapid, and no further reduction occurred after 18 to 24 days (Fig. 1). Final $g_{c}$ ranged from about $40 \%$ to $50 \%$ of values from control plants. The pattern of E mirrored that of $\mathrm{g}_{\mathrm{c}}$. These developmental results were confirmed in Expt. 3, when $\mathrm{A}_{\mathrm{CO}_{2}}$ of plants receiving $3 \mathrm{dS} \cdot \mathrm{m}^{-1}$ began declining relative to control plants by 12 to 17 days. Net $\mathrm{CO}_{2}$ assimilation declined to about $65 \%$ of $\mathrm{A}_{\mathrm{CO}_{2}}$ for control plants by day 39 .

Root zone salinity had no effect on the shape of the diurnal pattern of leaf gas exchange in Expt. 1. Generally, gas exchange increased from early to late morning and remained stable for several hours before a slow decline throughout the afternoon. The diurnal pattern of $\mathrm{A}_{\mathrm{CO}_{2}}, \mathrm{~g}_{\mathrm{c}}$, and $\mathrm{E}$ was dependent only on time of day $(P \leq 0.01)$ through day 14 . Beginning with day 19 , however, the diurnal pattern of gas-exchange variables was dependent on salinity stress and time of day (interaction $P \leq 0.01$ ). During the initial days of inhibition (e.g., day 19), $\mathrm{A}_{\mathrm{CO}_{2}}$ was decreased by

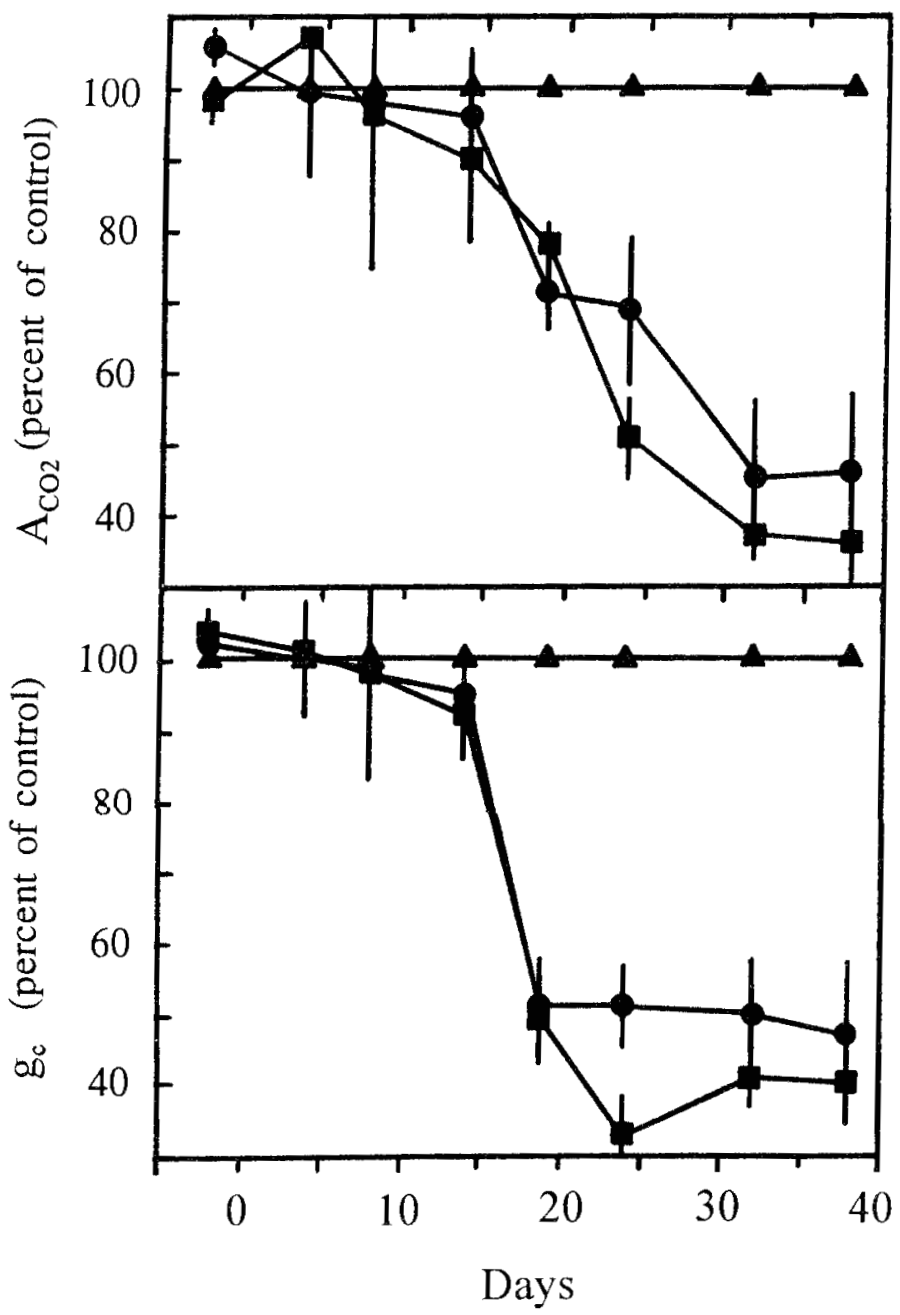

Fig. 1. Mean net $\mathrm{CO}_{2}$ assimilation (top) and stomatal conductance or $\mathrm{LU}_{2}$ (voutum) of Annona squamosa trees grown in sand culture as a function of time. Plants were irrigated with complete nutrient solution of $1 \mathrm{dS} \cdot \mathrm{m}^{-1}(\boldsymbol{\Delta})$ or with this solution amended with sea salt to $3(\mathbf{O})$ or $6(\boldsymbol{\square}) \mathrm{dS} \cdot \mathrm{m}^{-1}$. Treatments begun on 1 Apr. 1990 and measurements continued for 38 days. Each point represents the mean relative to control of six replications $\pm \mathrm{sE}$. salinity below that of control plants only during the middle part of each photoperiod (Fig. 2). Near the end of the study, however, $\mathrm{A}_{\mathrm{CO}_{2}}$ was decreased by salinity throughout the entire photoperiod (Fig. 2 ). The daily pattern for $\mathrm{g}_{\mathrm{c}}$ and $\mathrm{E}$ followed the same pattern as that of $\mathrm{A}_{\mathrm{CO}_{2}}$.

Data from the two midday measurements on day 38 of Expt. 1 were not different, therefore they were pooled to determine more precisely the influence of salinity on maximum flux (Table 1). The values of $\mathrm{A}_{\mathrm{CO}_{2}}$ and $\mathrm{g}_{\mathrm{c}}$ for plants receiving salinity ranged from about $30 \%$ to $50 \%$ of control plants. Water-use efficiency (WUE, $\mathrm{A}_{\mathrm{CO}_{2}} / \mathrm{E}$ ) was also reduced by salinity stress, due to a greater reduction of $\mathrm{A}_{\mathrm{CO}_{2}}$ than $\mathrm{E}$. This relationship of $\mathrm{A}_{\mathrm{CO}_{2}}, \mathrm{~g}_{\mathrm{c}}$, and WUE as influenced by salinity was confirmed in Expt. 5; however, absolute values of WUE were higher than those in Expt. 1.

$\mathrm{CO}_{2}$ dependence of $\mathrm{CO}_{2}$ assimilation. The response of $\mathrm{A}_{\mathrm{CO}_{2}}$ to external $\mathrm{CO}_{2}$ was linear within the range of 100 to $650 \mu \mathrm{l} \cdot \mathrm{liter}^{-1}$. The slope was defined as $\mathrm{CO}_{2}$-use efficiency and was greater for control than salt-stressed plants (Table 2).

Light dependence of $\mathrm{CO}_{2}$ assimilation. The percentage reduction of $\mathrm{A}_{\mathrm{CO}_{2}}$ by root zone salinity was fairly uniform over the PPF range of 250 to $1380 \mu \mathrm{mol} \cdot \mathrm{m}^{-2} \cdot \mathrm{s}^{-1}$. As a result, the shape of the $\mathrm{A}_{\mathrm{CO}_{2}}$ response to incident PPF at ambient $\mathrm{CO}_{2}$ was similar for the control and stressed A. squamosa trees (Fig. 3). Light saturation of $\mathrm{A}_{\mathrm{CO}_{2}}$ occurred for both groups of plants at about $700 \mu \mathrm{mol} \cdot \mathrm{m}^{-2} \cdot \mathrm{s}^{-1}$, and the plateau level of light saturated $\mathrm{A}_{\mathrm{CO}_{2}}$ at ambient $\mathrm{CO}_{2}$ was much

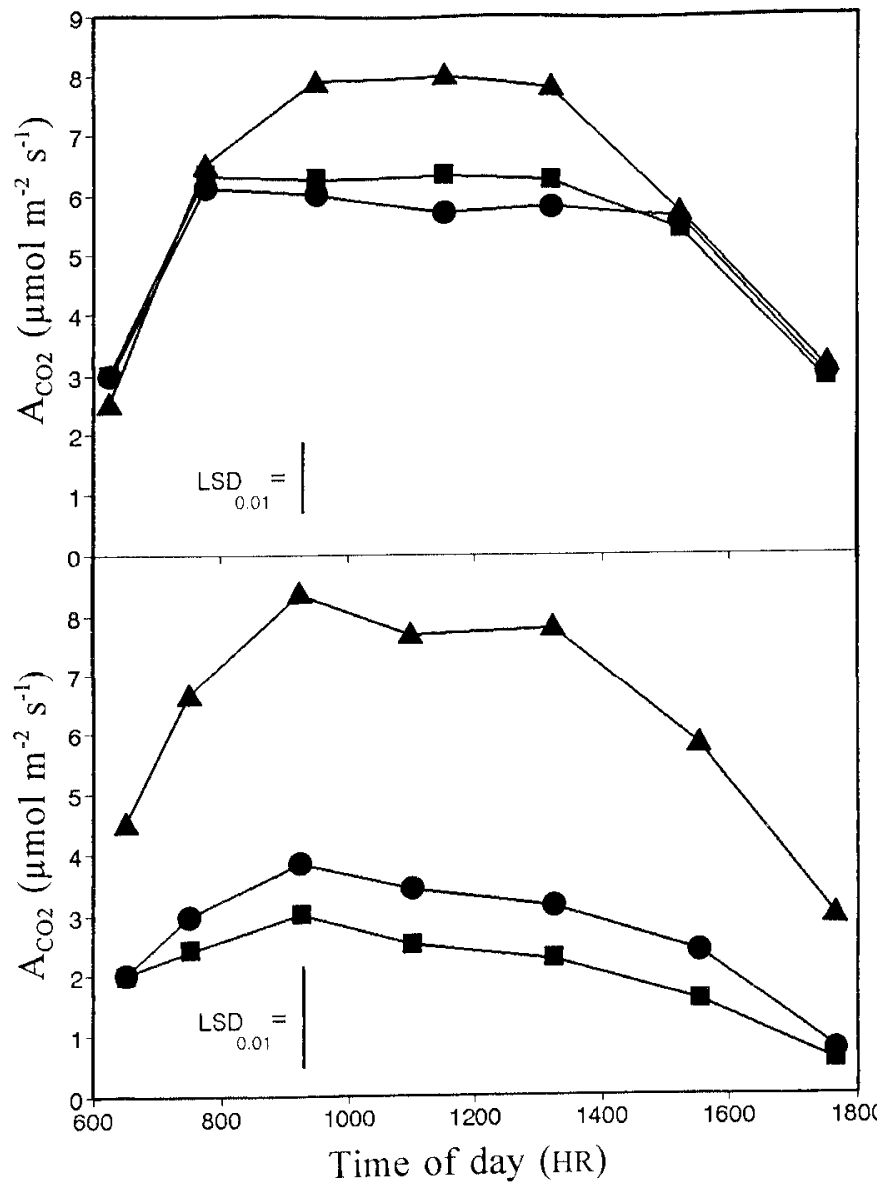

Fig. 2. The influence of time of day and salinity stress on net $\mathrm{CO}_{2}$ assimilation $\left(\mathrm{A}_{\mathrm{CO}_{2}}\right)$ of Annona squamosa leaves on day 19, 20 Apr. 1990 (top), and day 38, 9 May 1990 (bottom). Plants were irrigated with complete nutrient solution of 1 $\mathrm{dS} \cdot \mathrm{m}^{-1}(\boldsymbol{\Delta})$ or with this solution amended with sea salt to $3(\boldsymbol{O})$ or $6(\boldsymbol{\square}) \mathrm{dS} \cdot \mathrm{m}^{-1}$ Treatments were initiated on 1 Apr. 1990. $(n=6)$. 
Table 1. Influence of salinity on net $\mathrm{CO}_{2}$ assimilation $\left(\mathrm{A}_{\mathrm{CO}_{2}}\right)$, stomatal conductance of $\mathrm{CO}_{2}\left(\mathrm{~g}_{\mathrm{c}}\right)$, and water-use efficiency (WUE) of Annona squamosa plants. Treatments started on 1 Apr. 1990 and measurements were made 38 days later. $(\mathrm{n}=12)$.

\begin{tabular}{lccccc}
\hline \hline & \multicolumn{3}{c}{$\mathrm{dS} \cdot \mathrm{m}^{-1}$} & & \\
\cline { 2 - 6 } Characteristic & 1 & 3 & 6 & Significance & $\mathrm{r}^{2}$ \\
\hline $\mathrm{A}_{\mathrm{CO}_{2}}\left(\mu \mathrm{mol} \mathrm{CO}_{2} / \mathrm{m}^{2}\right.$ per sec $)$ & 7.7 & 3.2 & 2.2 & $\mathrm{Q}^{*}$ & $0.58^{\mathrm{z}}$ \\
$\mathrm{g}_{\mathrm{c}}\left(\mathrm{mmol} \mathrm{CO} / \mathrm{m}^{2}\right.$ per sec $)$ & 193 & 64 & 63 & $\mathrm{~L}^{* *}$ & 0.63 \\
WUE $\left(\mu \mathrm{mol} \mathrm{CO} / \mathrm{mmol} \mathrm{H}_{2} \mathrm{O}\right)$ & 1.0 & & & $\mathrm{Q}^{* *}$ & 0.37 \\
$\mathrm{~L}^{* *}$ & 0.5 & 0.57 & 0.34
\end{tabular}

${ }^{\mathrm{z} C o e f f i c i e n t}$ of simple determination.

${ }^{* * * *}$ Linear $(\mathrm{L})$ or quadratic $(\mathrm{Q})$ models are significant at $P \leq 0.05$ or 0.01 , respectively.

reduced by salinity. The slope of the linear non-light saturated portion of the curve $\left(<200 \mu \mathrm{mol} \cdot \mathrm{m}^{-2} \cdot \mathrm{s}^{-1}\right)$ was also reduced by salinity to $40 \%$ or $63 \%$ of control plants in Expt. 4 (Table 2) and Expt. 5 (data not shown), respectively. Dark respiration of $A$. squamosa leaves was not influenced by salinity. Mean $\mathrm{R}_{\mathrm{d}}$ was 2.3 \pm 0.4 or $2.5 \pm 0.3 \mu \mathrm{mol} \mathrm{CO} / \mathrm{m}^{2}$ per sec for plants receiving 1 or 3 $\mathrm{dS} \cdot \mathrm{m}^{-1}$ in Expt. 4 , and $1.6 \pm 0.3$ or $1.7 \pm 0.2 \mu \mathrm{mol} \mathrm{CO} / \mathrm{m}^{2}$ per sec for plants receiving 1 or $3 \mathrm{dS} \cdot \mathrm{m}^{-1}$ in Expt. 5. Mean $\mathrm{R}_{\mathrm{d}}$ of $A$. squamosa leaves represented a higher percentage of $\mathrm{A}_{\mathrm{CO}_{2}}$ for the plants under salinity stress than for the control plants. For instance, salinity stress raised $\mathrm{R}_{\mathrm{d}}: \mathrm{A}_{\mathrm{CO}_{2}}$ from 0.12 for control plants to 0.25 for plants receiving $3 \mathrm{dS} \cdot \mathrm{m}^{-1}$ in Expt. 5 .

Chlorophyll fluorescence. Salinity reduced $\mathrm{F}_{\mathrm{v}}: \mathrm{F}_{\mathrm{m}}$ upon induction following a period of dark acclimation in Expt. 3 (Table 2). However, in Expt. 5, the dependence of $\mathrm{F}_{\mathrm{v}}: \mathrm{F}_{\mathrm{m}}$ on salinity exhibited a dependence on the amount of ambient light during the morning on each day of measurement. On overcast days, $\mathrm{F}_{\mathrm{v}}: \mathrm{F}_{\mathrm{m}}$ did not decline for plants receiving $1 \mathrm{dS} \cdot \mathrm{m}^{-1}(0.79 \pm 0.03)$ or $3 \mathrm{dS} \cdot \mathrm{m}^{-1}(0.80$ $\pm 0.03)$. On days with full sun conditions, $\mathrm{F}_{\mathrm{v}}: \mathrm{F}_{\mathrm{m}}$ of all plants was reduced to a similar degree by midday (following several hours of exposure to direct sun). As a result, $\mathrm{F}_{\mathrm{v}}: \mathrm{F}_{\mathrm{m}}$ did not differ for plants receiving $1 \mathrm{dS} \mathrm{m} \mathrm{m}^{-1}(0.60 \pm 0.03)$ or $3 \mathrm{dS} \cdot \mathrm{m}^{-1}(0.61 \pm 0.03)$. However, the plants under salinity stress had significantly lower $\mathrm{F}_{\mathrm{v}}: \mathrm{F}_{\mathrm{m}}$ than the control plants during midday on all partly cloudy days. The morning of 4 Sept. 1993, for example, was characterized by sunny conditions frequently interrupted by broken cumulus cloud cover. Following the first half of the photoperiod under these conditions, $\mathrm{F}_{\mathrm{v}}: \mathrm{F}_{\mathrm{m}}$ was $0.72 \pm 0.03$ for control plants and $0.65 \pm 0.03$ for salinity-stressed plants.

Water relations. Mild salinity did not influence $\psi_{\mathrm{x}}$ in Expt. 5, where the mean for plants in each treatment level was $-0.6 \pm 0.1$ $\mathrm{MPa}$. Fully hydrated root tissue $\psi_{\pi}$ was more negative for plants receiving salinity than for control plants (Table 2). In contrast, $\psi_{\pi}$ of fully hydrated leaves did not differ among the treatments, and was $-2.2 \pm 0.1$ or $-2.3 \pm 0.1 \mathrm{MPa}$ for plants receiving 1 or $3 \mathrm{dS} \cdot \mathrm{m}^{-1}$, respectively.

Mineral content. Mild salinity of $3 \mathrm{dS} \cdot \mathrm{m}^{-1}$ administered for 52 days to A. squamosa plants did not influence foliar calcium, potassium, and sodium concentrations, which averaged 19, 12, and $10 \mathrm{~g} \cdot \mathrm{kg}^{-1}$, respectively. The ratio of sodium to potassium was also unaffected by salinity. However, nitrogen concentration decreased and chloride concentration increased in foliage of salt-stressed plants compared with foliage of control plants (Table 2).

\section{Discussion}

This report contains the first description of the photosynthetic characteristics of $A$. squamosa. Maximum values of $\mathrm{A}_{\mathrm{CO}_{2}}, \mathrm{~g}_{\mathrm{c}}$, and $\mathrm{E}$ are within the range expected for woody evergreen species. The responses of $\mathrm{A}_{\mathrm{CO}_{2}}$ to PPF and external $\mathrm{CO}_{2}$, diurnal pattern are similar to other woody perennial fruit species (Flore and Lakso, 1990; Korner et al., 1979).

Salt tolerance of $A$. squamosa has not been previously determined (Maas, 1994). We did not obtain any yield or growth data. However, the measurements of maximum $\mathrm{A}_{\mathrm{CO}_{2}}$ as influenced by the low dose levels of salinity in this study, accepted relationships of soil or irrigation water EC to that of a saturated-soil extract (Farnham et al., 1985), and the published tolerance levels of Maas and Hoffman (1977) indicate that A. squamosa is sensitive to salinity stress.

Although chloride concentration increased in the foliage of these seedlings, sodium concentration was unaffected by mild salinity. Notwithstanding the relative intolerance of A. squamosa to salinity stress, some form of sodium exclusion or compartmentation in roots

Table 2. Influence of salinity on fluorescence ratio $\left(\mathrm{F}_{\mathrm{v}}: \mathrm{F}_{\mathrm{m}}\right)$, slope of photosynthetic response to external $\mathrm{CO}_{2}$, initial slope of photosynthetic response to irradiance, root tissue osmotic potential $\left(\psi_{\pi}\right)$, and foliar chloride and nitrogen content of Annona squamosa plants.

\begin{tabular}{|c|c|c|c|c|}
\hline \multirow[b]{2}{*}{ Characteristic } & \multirow[b]{2}{*}{ Experiment $^{\mathrm{z}}$} & \multicolumn{2}{|c|}{$\mathrm{dS} \cdot \mathrm{m}^{-1}$} & \multirow[b]{2}{*}{ Significance $(P)$} \\
\hline & & 1 & 3 & \\
\hline $\mathrm{F}_{\mathrm{v}}: \mathrm{F}_{\mathrm{m}}$ & 3 & 0.6 & 0.4 & 0.05 \\
\hline $\begin{array}{l}\mathrm{CO}_{2} \text { response } \\
\left(\mu \mathrm{mol} \mathrm{CO} / \mathrm{m}^{2} \text { per sec per } \mu \mathrm{CO}_{2} / \text { liter }\right)\end{array}$ & 2 & 0.023 & 0.009 & $0.01^{\mathrm{y}}$ \\
\hline $\begin{array}{l}\text { Light response } \\
\left(\mu \mathrm{mol} \mathrm{CO}_{2} / \mu \mathrm{mol} \text { photons }\right)\end{array}$ & 4 & 0.03 & 0.01 & $0.05^{\mathrm{y}}$ \\
\hline $\operatorname{Root} \psi_{\pi}(\mathrm{MPa})$ & 5 & -1.05 & -1.39 & 0.05 \\
\hline Chloride $\left(\mathrm{g} \cdot \mathrm{kg}^{-1}\right)$ & 5 & 16.4 & 45.5 & 0.01 \\
\hline Nitrogen $\left(\mathrm{g} \cdot \mathrm{kg}^{-1}\right)$ & 5 & 20.9 & 17.4 & 0.01 \\
\hline
\end{tabular}

${ }^{\mathrm{z}}$ See text for details on starting and measurement dates for each experiment.

${ }^{\mathrm{y}}$ Analysis of covariance test for homogeneity of slopes. 


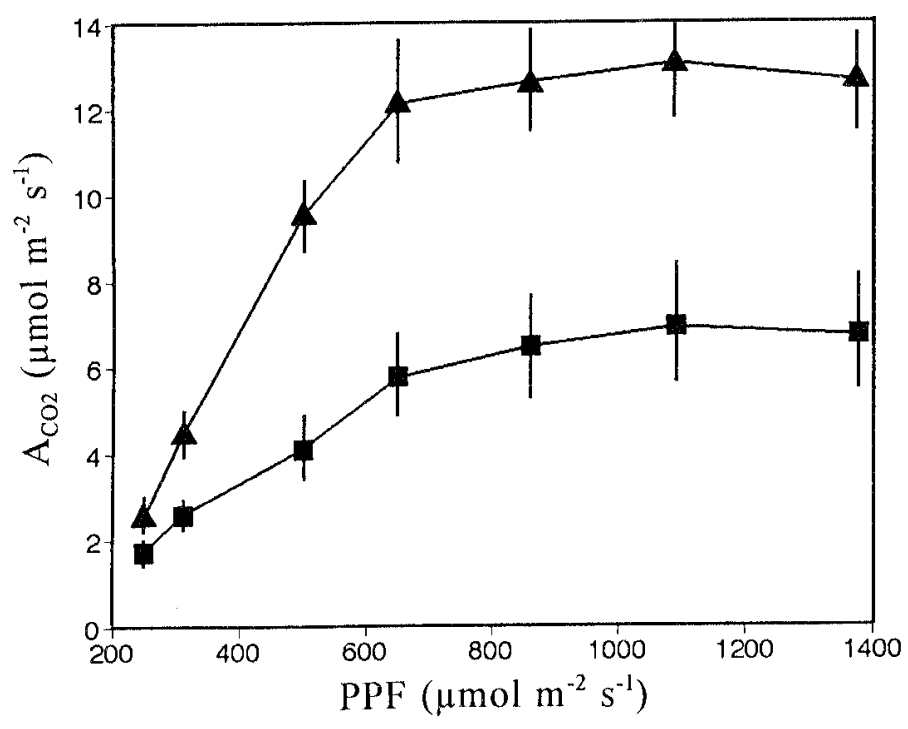

Fig. 3. Net $\mathrm{CO}_{2}$ assimilation $\left(\mathrm{A}_{\mathrm{CO}_{2}}\right)$ of Annona squamosa leaves as a function of photosynthetic photon flux (PPF). Plants were grown in sand and irrigated with complete nutrient solution of $1 \mathrm{dS} \cdot \mathrm{m}^{-1}(\mathbf{\Delta})$ or with this solution amended with sea salt to $3 \mathrm{dS} \cdot \mathrm{m}^{-1}(\mathbf{O})$. Each point represents the mean of six replications $\pm \mathrm{SE}$ determined on 27 Aug. 1993, 37 days after treatments were initiated.

or stems occurred in these seedlings to minimize movement of sodium into foliage. Further analysis of root, stem, and leaf mineral relations of plants under salinity stress is needed to characterize this mechanism.

Ambient light conditions are highly variable in the lowland tropics. Large cumulus clouds are numerous even on days that are classified as mostly sunny. Passage of these clouds frequently reduces PPF to the range where $\mathrm{A}_{\mathrm{CO}_{2}}$ of most plants is light-limited. As a result, an understanding of the photosynthetic response to light is needed over the entire light curve to determine more fully the daily carbon balance for any species in the lowland tropics. Salinity did not change the shape of the light response curve or the approximate PPF at which $\mathrm{A}_{\mathrm{CO}_{2}}$ became light-saturated. Rather, salinity-induced decreases in $\mathrm{A}_{\mathrm{CO}_{2}}$ were homogeneous across the response curve. A similar reduction in $\mathrm{A}_{\mathrm{CO}_{2}}$ of salt-stressed guava plants over the entire light response curve was reported by Walker et al. (1979).

WUE is an important aspect in tolerance of salt stress. The reduction in WUE of stressed A. squamosa (Table 1) is in agreement with some previous reports; however, WUE has also been unaffected or increased by salinity (Hoffman and Phene, 1971).

Reported effects of salinity on respiration vary greatly with salinity level and genotype (Gale, 1975). Respiration of tolerant plants may increase at low levels of salinity, while respiration of intolerant species may show a decrease or no change in response to salt stress (Schwarz and Gale, 1981). The lack of salinity effect on $\mathrm{R}_{\mathrm{d}}$ of $A$. squamosa was expected given the relative intolerance indicated by the large reduction of $\mathrm{A}_{\mathrm{CO}_{2}}$ at mild salinity.

Although we did not measure $\mathrm{R}_{\mathrm{d}}$ throughout the development in Expts. 1 and 3, we assume $\mathrm{R}_{\mathrm{d}}$ did not differ among treatments based on the ending measurements. The daily loss of carbon through respiration of the salinized plants became a larger percentage of the daily carbon gain the day $\mathrm{A}_{\mathrm{CO}_{2}}$ started to decline. As a result, plants under salinity stress not only declined in carbon acquisition capacity but increased in the proportional carbon loss by respiration..

The ratio $\mathrm{F}_{\mathrm{v}}: \mathrm{F}_{\mathrm{m}}$ is considered an effective indicator of photochemical efficiency loss. Determining $\mathrm{F}_{\mathrm{v}}: \mathrm{F}_{\mathrm{m}}$ may provide a rapid test for monitoring the effects on the photosynthetic apparatus of various stresses (Bolhar-Nordenkampf et al., 1989). Salinity reduced $\mathrm{F}_{\mathrm{v}}$ in other species, for example, olive (Olea europea L.) (Bongi and Loreto, 1989). In this study, there was a complex interaction between light accumulation during each photoperiod and the influence of salinity on chlorophyll fluorescence of $A$. squamosa leaves. Mild salinity did not influence $\mathrm{F}_{\mathrm{v}}: \mathrm{F}_{\mathrm{m}}$ of this species (compared with unstressed trees) on overcast days with limited light or on clear days with full sun conditions. The photochemical efficiency of salinity-stressed plants declined more than in nonstressed plants, however, on partly cloudy days. These relationships are not surprising since light stress is not a result of the absolute light level, but the excess amount of light not used in photosynthesis (Demmig-Adams and Adams, 1992). A midday reduction in $\mathrm{F}_{\mathrm{v}}: \mathrm{F}_{\mathrm{m}}$ is a widespread response to sunny conditions for plants without any apparent edaphic stress (Marler, 1994). The natural reduction in $\mathrm{F}_{\mathrm{v}}: \mathrm{F}_{\mathrm{m}}$ is correlated with cumulative light load during the morning (Marler et al., 1994) and is of much greater magnitude than any reduction in $\mathrm{F}_{\mathrm{v}}: \mathrm{F}_{\mathrm{m}}$ resulting from salinity in this study. For these reasons, we do not feel that fluorescence is a stable indicator of salinity stress. Despite the many variables that can complicate gas-exchange data, our gas-exchange measurements provided more stable daily responses than the fluorescence measurements. Possibly $\mathrm{F}_{\mathrm{v}}: \mathrm{F}_{\mathrm{m}}$ would be less variable with the use of a specific PPF level and duration before fluorescence measurements, rather than relying on ambient light conditions.

In summary, $\mathrm{A}_{\mathrm{CO}_{2}}, \mathrm{~g}_{\mathrm{c}}, \mathrm{E}$, and WUE of $A$. squamosa were reduced by mild salt stress caused by enrichment with sea salt. Salinity also reduced $\mathrm{CO}_{2}$ - and light-use efficiencies. Only the amplitude, not the shape of the $\mathrm{A}_{\mathrm{CO}_{2}}$ response curve to PPF and time of day, was altered by salinity stress. Sodium concentrations in the foliage of the salt-stressed plants did not increase, but foliage chloride concentration did increase. These results suggest that $A$. squamosa is sensitive to salinity stress and responds to mild salinity in a manner similar to other sensitive woody perennial species.

\section{Literature Cited}

Bolhar-Nordenkampf, H.R., S.P. Long, N.R. Baker, G. Oquist, U. Schreiber, and E.G. Lechner. 1989. Chlorophyll fluorescence as a probe of the photosynthetic competence of leaves in the field: A review of current instrumentation. Functional Ecol. 3:497-514.

Bongi, G. and F. Loreto. 1989. Gas-exchange properties of salt-stressed olive (Olea europea L.) leaves. Plant Physiol. 90:1408-1416.

Demmig-Adams, B. and W.W. Adams III. 1992. Photoprotection and other responses of plants to high light stress. Annu. Rev. Plant Physiol. Plant Mol. Biol. 43:599-626.

Farnham, D.S., R.F. Hasek, and J.L Paul. 1985. Water quality: Its effects on ornamental plants. Univ. of Calif. Coop. Ext. Leaflet 2995.

Flore, J.A. and A.N. Lakso. 1990. Environmental and physiological regulation of photosynthesis in fruit crops. Hort. Rev. 11:111-157.

Gale, J. 1975. Water balance and gas exchange of plants under saline conditions, p. 168-185. In: A. Poljakoff-Mayber and J. Gale (eds.). Plants in saline environments. Springer-Verlag, New York.

Hoagland, D.R. and D.I. Arnon. 1950. The water culture method for growing plants without soil. Calif. Agr. Expt. Sta. Circ. 347.

Hoffman, G.J. and C.J. Phene. 1971. Effect of constant salinity levels on water-use efficiency of bean and cotton. Trans. Amer. Soc. Agr. Eng. 14:1103-1106.

Keleg, F.M., E.M. El-Azab, and M. Sourour. 1980. Effect of soil and salinity on growth and mineral content of leaves and roots of loquat, annona, and papaya seedlings. Alexandria J. Agr. Res. 28:213-224.

Korner, C.H., J.A. Scheel, and H. Bauer. 1979. Maximum leaf diffusive conductance in vascular plants. Photosynthetica 13:45-82.

Maas, E.V. 1994. Tolerance and responses of tropical crops to salinity stress, p. 47-56. In: T.L. Davenport and H.M. Harrington (eds.). Pro- 
ceedings of plant stress in the tropical environment. Kailua-Kona, HI, 20-25 Sept. 1992.

Maas, E.V. and G.J. Hoffman. 1977. Crop salt tolerance-Current assessment. J. Irr. Drain. Div., Amer. Soc. Chem. Eng. 103(IR2):115-134.

Markhart, A.H. III and T.Y. Lin. 1985. New hand-operated press for the extraction of tissue sap for the measurement of osmotic potential. Agron. J. 77:182-185.

Marler, T.E. 1994. Nocturnal and diurnal patterns of chlorophyll fluorescence, p. 123-124. In: T.L. Davenport and H.M. Harrington (eds.). Proceedings of plant stress in the tropical environment. Kailua-Kona, HI, 20-25 Sept. 1992.

Marler, T.E. and M.V. Mickelbart. 1992. Repeated mechanical stress from leaf cuvette influences leaf gas exchange. HortScience 27:432434

Marler, T.E., M.V. Mickelbart, and R. Quitugua. 1993. Papaya ringspot virus influences net gas-exchange of papaya leaves. HortScience 28:322_ 324.

Marler, T.E., B. Schaffer, and J.H. Crane. 1994. Developmental light level affects growth, morphology, and leaf physiology of young carambola trees. J. Amer. Soc. Hort. Sci. 119:711-718.

Morton, J.F., 1987. Fruits of warm climates. Creative Resource Systems, Winterville, N.C.

Munns, R. and A. Termaat. 1986. Whole-plant responses to salinity. Austral. J. Plant Physiol. 13:143-160.

Schwarz, M. and J. Gale. 1981. Maintenance respiration and carbon balance of plants at low levels of sodium chloride salinity. J. Expt. Bot. 32:933-941.

Singh, P., T. Marler, and M. Marutani. 1994. Micronesia, p. 3. In: T.L. Davenport and H.M. Harrington (eds.). Proceedings of plant stress in the tropical environment. Kailua-Kona, HI, 20-25 Sept. 1992.

Walker, R.R., P.E. Kriedemann, and D.H. Maggs. 1979. Growth, leaf physiology and fruit development in salt-stressed guavas. Austral. J. Agr. Res. 30:477-488.

Wolf, B. 1982. A comprehensive system of leaf analyses and its use for diagnosing crop nutrient status. Commun. Soil Sci. Plant Anal. 13(12):1035-1059.

Yeo, A.R. 1983. Salinity resistance: physiologies and prices. Physiol. Plant. 58:214-222. 